\section{Physiological methods as indexes of listening effort measurement: an integrative literature review}

Laura Mochiatti Guijo(1) Ana Cláudia Vieira Cardoso(1)

(1) Faculdade de Filosofia e Ciências da Universidade Estadual Paulista Júlio de Mesquita Filho - UNESP, Marília, São Paulo, Brasil.

Conflict of interests: Nonexistent

\section{(c) (i)}

Received on: March 20, 2018 Approved on: June 25, 2018

\section{Corresponding author:}

Laura Mochiatti Guijo

Rua Guiro Shimabukuro, 106,

Parque das Acácias

CEP: 17510-050 - São Paulo, São Paulo, Brasil

E-mail: lauramochiatti@gmail.com

\section{ABSTRACT}

Purpose: to review the scientific literature and present existing instruments and methods for the objective assessment of the listening effort in normal hearing individuals worldwide.

Methods: a literature integrative review whose purpose was to gather and summarize the scientific knowledge regarding the objective methods theme for measuring the listening effort, developed through the search of articles in specialized national and international journals, in the English and Portuguese languages, available in the databases: PUBMED, Cochrane Library, LILACS and SCIELO.

Results: 18 articles which used physiological methods to measure the listening effort in individuals with normal hearing were reviewed. The main findings described in those articles refer to the author(s) and purpose(s) of the research, country where the research was conducted, casuistry, physiological method used and results.

Conclusion: there is no consensus among the researchers about the best physiological method to measure this parameter, that is, this effort in the speech perception tasks, although the level of skin conductance is considered the most accurate measure to date.

Keywords: Hearing; Cognition; Heart Rate; Pupil; Galvanic Skin Response 


\section{INTRODUCTION}

In recent years, the areas of cognitive psychology and audiology have been dedicating to find the most appropriate method to measure listening effort, using different instruments to quantify this phenomenon both through subjective procedures and objective procedures. In the subjective assessment, questionnaires ${ }^{1,2}$, classification scales ${ }^{3}$ or self-report methods have been used. Although these methods are easy and quick to apply, the use of an objective method to quantify such cognitive effort in clinical settings would be invaluable in obtaining more accurate and reliable results.

In the literature, there are different approaches to estimate listening effort objectively. One of the measurement methods employed by researchers who study this topic is pupillometry ${ }^{4-6}$. In these studies, the speech stimulus used to the listening effort assessment were sentences presented in different signal-to-noise ratios, the expected response was the repetition of these sentences and the increase in pupil diameter was interpreted as an increase of the listening effort.

Other studies used different physiological measures to investigate and quantify the listening effort, including heart rate variability (HRV), skin conductance and temperature, and electromyographic (EMG) activity. The authors stated that these measures could be used as possible indexes of listening effort ${ }^{7}$.

As well as in pupillometry studies, physiological data were recorded during a speech recognition task and, as far as the task demand increased, electromyographic activity and skin conductance also increased.

Authors $^{8-10}$ reported that changes in cardiac measurements and skin conductance are commonly noticed when mental demands of the tasks are increased. Other authors ${ }^{11,12}$ determined changes in breath, electromyography, electroencephalography activity and skin temperature during listening effort assessment, but these measurements were less consistent to quantify this effort.

A review study on listening effort ${ }^{13}$ concluded that the lack of uniformity in the methods employed for the assessment of this parameter is due to the different assumptions of the professionals involved in the area. Therefore, these authors ${ }^{13}$ recommended that researchers consider these assumptions in interpreting their data and, whenever possible, make predictions based on current theoretical knowledge to increase understanding about the underlying mechanisms of listening effort.
Although the international literature presents several studies that measure the listening effort objectively, there is still no consensus in relation to the best index to assess this parameter.

Knowing the research and the instruments of objective assessment of the listening effort that have been used in the national and international scope is the first step for the training of the audiologist who works in this area and this domain will allow the choice of the best assessment method. In this way, the purposes of this article were to review the scientific literature and present the existing instruments and methods for the objective assessment of the listening effort in normal hearing individuals throughout the world.

\section{METHODS}

As living beings were not used, it was not necessary to approve this work by the Research Ethics Committee.

The present article presents as a method the integrative literature review, whose purpose is to gather and summarize the scientific knowledge produced in respect of the thematic investigated, allowing the evaluation and synthesis of the available evidence, collaborating for the development of this subject ${ }^{14}$. This review was performed according to the following stages: identification of the research question; search in the literature through the establishment of criteria, such as: keywords, inclusion and exclusion criteria; evaluation and analysis of the studies included in the bibliographic review; review presentation and knowledge synthesis ${ }^{15}$.

In order to guide the search and discussion of the studies, the following question was formulated: "What existing methods have been used to assess listening effort objectively in normal hearing individuals on the world scenario?". In order to obtain answers to this question, a collection of articles was performed in specialized national and international journals, both in English and Portuguese languages, available in the following databases: US National Library of Medicine National Institutes of Health (PUBMED), Cochrane Library, Biblioteca Vitual em Saúde - Literatura LatinoAmericana e do Caribe em Ciências da Saúde (LILACS) and Scientific Electronic Library Online (SCIELO), specifically in each base and without limiting the search period.

In order to collect the articles, it was defined terms related to the "listening effort", found in the Descriptors in Health Sciences (Descritores em Ciências da Saúde - DeCS), in the Medical Subject Headings (MeSH) and, keywords related to the topic, combined among 
them with the use of the Boolean operators AND and OR. The terms chosen for the search were used in an isolated and crossed way (Figure 1). In all searches the "word" filter was used.

\begin{tabular}{|c|c|}
\hline Search number & Words and descriptors crossed \\
\hline 01 & Normal hearing \\
\hline 02 & Audição normal \\
\hline 03 & Listening effort \\
\hline 04 & Esforço auditivo \\
\hline 05 & Objective assessment \\
\hline 06 & Avaliação objetiva \\
\hline 07 & Pupillometry \\
\hline 08 & Pupilometria \\
\hline 09 & Heart Variability Frequency \\
\hline 10 & Variabilidade da frequência cardíaca \\
\hline 11 & Skin conductance \\
\hline 12 & Condutância da pele \\
\hline
\end{tabular}

Figure 1. Relation of words and descriptors of topics used in the literature search

Initially, the inclusion or exclusion of the articles was based on the information contained in the title and in the abstract, but if this information was not explicit in relation to the researched topic, the article was read for the fulfilment of the following inclusion criteria: articles that used objective methods to assess the listening effort in subjects with normal hearing. All articles about listening effort that used only self-report methods, questionnaires, subjective scales and dual-task paradigms were excluded; studies on assessment of listening effort in populations with hearing loss; studies with animals; articles to which only abstract and/or abstract were available, and literature review articles.

The analysis of the studies was initially based on the reading of the titles and abstracts, followed by the full reading of the articles that fit the selection criteria. Each article was evaluated by one of the authors and, in case of uncertainty, there was a consensus among all authors with respect the inclusion of the article.

Publications that were classified as eligible for this review were read by at least one of the authors. The main characteristics of the selected studies and the physiological indexes used to measure the listening effort were organized in a figure format.

For the data organization, the articles that resulted from each crossed term were computed, which were repeated in relation to the previous search and that were related to the present study.

In the analysis of the selected studies, the following data were considered: authors and purpose(s) of the research, country where the research was conducted, casuistry, physiological method employed and results.

\section{LITERATURE REVIEW}

From the search carried out in the PUBMED, Cochrane library, LILACS and SCIELO databases, 206 articles were found, and each article was presented in one or more databases. In the reading of the abstracts of these articles, those that had previously been selected in other databases, those that did not fit the inclusion criteria, and the journals to which complete articles were not available during the search period were excluded.

From this total of 206 articles, the abstracts were read and 56 articles were discarded because the participants had hearing loss, 16 because the texts were unavailable, 24 because they were studies whose assessment method of the listening effort was subjective, 69 did not address the listening effort topic, 18 due to duplicity, 4 were literature review studies and 1 was an experimental study developed with animals. 
After this detailed analysis, 18 articles were selected that met the criteria established for this review.

The selection process of the studies included in this literature review is illustrated in the figure format (Figure 2).
The synthesis of the articles that presents information about the authors and purpose(s) of the research, country where the research was conducted, casuistry, physiological method employed and results of the studies is shown in Figure 3.

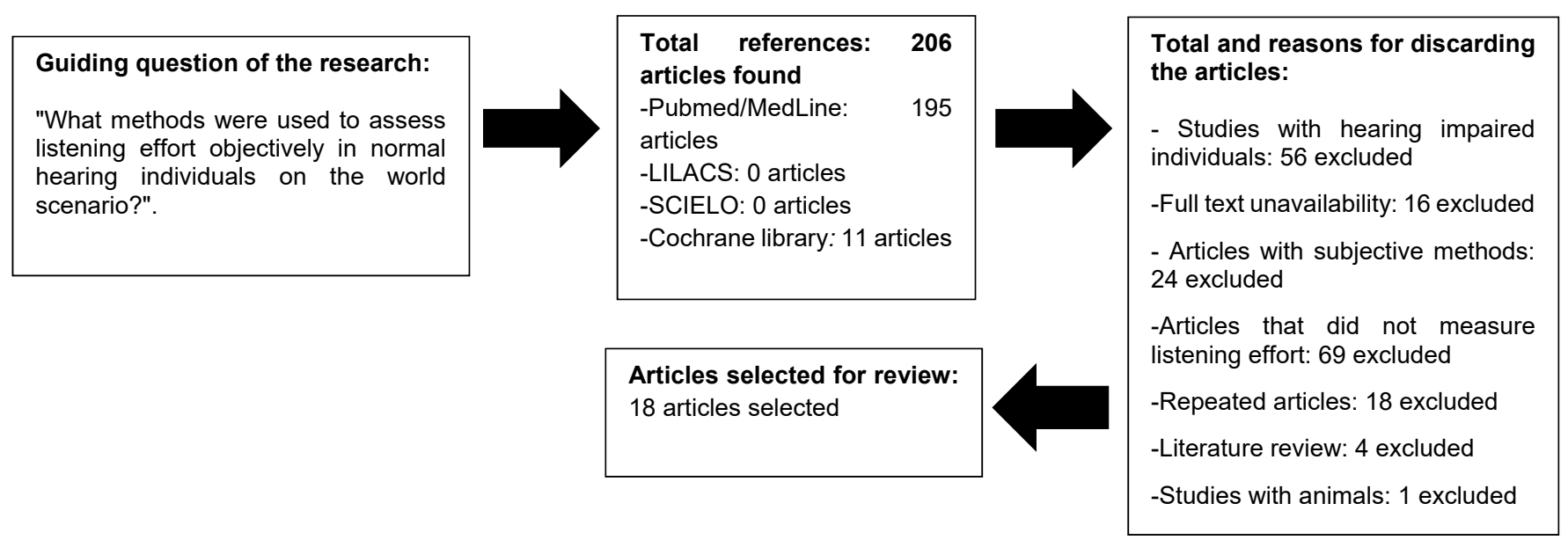

Figure 2. Flowchart of the selection of reviewed and analyzed articles

The current article presents an overview of the studies that used physiological methods to assess listening effort objectively in subjects with normal hearing and their comprehensiveness on the world scenario. It should be emphasized that this review was conducted according to the guidelines for an integrative literature review, since it was not intended to evaluate the quality of the included studies, but describe the previous publications in order to provide an overview of the studies developed so far about the topic listening effort, and the measurement of this parameter in an objective way.

Specifically, the purposes of this review were to present the existing physiological indexes that are used to measure the listening effort in normal hearing individuals in the world scenario and to provide a synthesis of the results obtained.

Based on the analyzed studies, it was possible to infer that among the physiological indexes used for the listening effort measurement and presented in the reviewed articles, the level of skin conductance was demonstrated to be the most accurate and promising measurement in the quantification of this effort ${ }^{7,20}$. Authors stated that the increase in skin conductance occurred due to excitation of the sympathetic nervous system as a consequence of the increase in the demand for the performing of the speech perception task $^{22}$.

Physiological indexes such as heart rate, skin temperature ${ }^{7}$ and pupillometry ${ }^{17}$ did not undergo significant changes that proved the listening effort employed in the speech perception task in normal individuals.

However, a study reported that pupil dilation, noticed during the application of speech perception tests, especially in adverse situations, reflects the auditory and cognitive processes required for the resolution of the listening task ${ }^{28}$.

Another study investigated by means of the pupillometry if the processing effort of musicians and non-musicians is different. The results demonstrated that the musicians dispensed less listening effort when performing a speech perception task in different signal-to-noise ratios during the pupillometry recording probably due to their musical abilities ${ }^{19}$.

In the majority of the reviewed studies the population assessed was composed of young adults, being only a study conducted with a child population ${ }^{17}$. 


\begin{tabular}{|c|c|c|c|c|}
\hline Author/year/purpose(s) & Country & Casuistry & $\begin{array}{l}\text { Physiologi- } \\
\text { cal Method }\end{array}$ & Results \\
\hline $\begin{array}{l}\text { Miles et al., } 2017^{16} \\
\text { Purpose(s): To determine if pupil dilatation and alpha } \\
\text { power change are similar indexes for assessing listening } \\
\text { effort and if they assess similar processes. }\end{array}$ & Australia & $\begin{array}{l}27 \text { English adult } \\
\text { individuals with } \\
\text { normal hearing. }\end{array}$ & $\begin{array}{l}\text { Pupillometry } \\
\text { and EEG. }\end{array}$ & $\begin{array}{l}\text { The two measures did not correlate, suggesting that each } \\
\text { of them may reflect different cognitive processes involved } \\
\text { in the listening effort. }\end{array}$ \\
\hline $\begin{array}{l}\text { McGarrigle, Dawes, Stewart, Kuchinsky, Munro, } 2017^{17} \\
\text { Purpose(s): To investigate the effect of the relation (S/N) } \\
\text { in classrooms on the listening effort (behavioral and pu- } \\
\text { pillometry) and to relate it to fatigue (self-report and pu- } \\
\text { pillometry) in a group of school-age children. }\end{array}$ & $\begin{array}{l}\text { The United } \\
\text { States of } \\
\text { America }\end{array}$ & $\begin{array}{l}41 \text { normal hearing } \\
\text { children and age } \\
\text { from eight to } 11 \\
\text { years. }\end{array}$ & Pupillometry & $\begin{array}{l}\text { The pupillometry findings did not show significance in the } \\
\text { studied population (children) for the listening effort mea- } \\
\text { surement. }\end{array}$ \\
\hline $\begin{array}{l}\text { Wagner; Toffanin, Baskent, } 2016^{18} \\
\text { Purpose(s): To compare the automatic process of lexical } \\
\text { competition between natural and degraded speech, and } \\
\text { to combine eye fixations that capture the course of lexi- } \\
\text { cal disambiguation with pupillometry that quantifies the } \\
\text { mental effort involved in speech processing. }\end{array}$ & $\begin{array}{l}\text { Nether- } \\
\text { lands }\end{array}$ & $\begin{array}{l}73 \text { normal hearing } \\
\text { adults and age } \\
\text { between } 20 \text { and } 31 \\
\text { years. }\end{array}$ & Pupillometry & $\begin{array}{l}\text { The degradation of the signal or receiver channel can lead } \\
\text { to increased mental effort. The incomplete and effortless } \\
\text { processing in the early pre-lexical stages has its conse- } \\
\text { quences in the lexical processing, since it adds uncer- } \\
\text { tainty to the formation. }\end{array}$ \\
\hline $\begin{array}{l}\text { Bianchi, Santurette, Wendt, Dau, } 2016^{19} \\
\text { Purpose(s): To investigate the perceptual improvement of } \\
\text { behavioral and objective way for complex harmonic and } \\
\text { non-harmonic tones to clarify if the performance in musi- } \\
\text { cians can be attributed to the increase of the peripheral } \\
\text { frequency selectivity and/or if the processing effort is dif- } \\
\text { ferent in the accomplishment of the task. }\end{array}$ & Denmark $^{19}$ & $\begin{array}{c}10 \text { normal-hearing } \\
\text { musicians, with } \\
\text { more than four } \\
\text { years of formal } \\
\text { music training and } \\
10 \text { normal-hearing } \\
\text { non-musicians } \\
\text { without formal } \\
\text { music training. Age } \\
\text { ranged from } 23 \text { to } \\
28 \text { years. } \\
\end{array}$ & Pupilometry & $\begin{array}{l}\text { The pupillometry responses indicated less processing ef- } \\
\text { fort in musicians versus non-musicians. }\end{array}$ \\
\hline $\begin{array}{l}\text { Wendt, Dau, Hjortkiær, } 2016^{20} \\
\text { Purpose(s): To distinguish between the results obtained } \\
\text { by the self-perception of the listening effort rate versus } \\
\text { pupil dilation. }\end{array}$ & $\begin{array}{c}\text { The United } \\
\text { States of } \\
\text { America }\end{array}$ & $\begin{array}{l}11 \text { women and } 9 \\
\text { men with normal } \\
\text { hearing. }\end{array}$ & Pupillometry & $\begin{array}{l}\text { The pupil dilatation and listening effort subjectively as- } \\
\text { sessed represent different aspects of this effort. }\end{array}$ \\
\hline $\begin{array}{l}\text { Francis, MacPherson, Chandrasekaran, Alvar, } 2016^{21} \\
\text { Purpose(s): To measure the physiological reactivity as- } \\
\text { sociated with three degraded listening conditions, each of } \\
\text { which differed in relation to the difficulty level in order to } \\
\text { engage different cognitive mechanisms. }\end{array}$ & $\begin{array}{l}\text { The United } \\
\text { States of } \\
\text { America }\end{array}$ & $\begin{array}{l}14 \text { American } \\
\text { English speakers, } \\
\text { students from the } \\
\text { Purdue University. }\end{array}$ & $\begin{array}{l}\text { Skin con- } \\
\text { ductance, } \\
\text { blood pulse } \\
\text { amplitude, } \\
\text { and pulse } \\
\text { rate. } \\
\end{array}$ & $\begin{array}{l}\text { Future research is needed to distinguish between the } \\
\text { physiological and behavioral consequences of the stress } \\
\text { and cognitive demand on speech processing in adverse } \\
\text { conditions. }\end{array}$ \\
\hline $\begin{array}{l}\text { Mackersie, Calderon-Moultrie, } 2016^{22} \\
\text { Purpose(s): To present current results of a new study } \\
\text { with normal listeners that assessed the effects of speech } \\
\text { rate on changes in skin conductance and high frequency } \\
\text { HRV (HF-HRV). }\end{array}$ & $\begin{array}{l}\text { The United } \\
\text { States of } \\
\text { America }\end{array}$ & $\begin{array}{l}26 \text { young adults } \\
(9 \text { males and } 17 \\
\text { females) aged } \\
\text { between } 20 \text { and } 35 \\
\quad \text { years. }\end{array}$ & $\begin{array}{l}\text { ECG and } \\
\text { skin conduc- } \\
\text { tance. }\end{array}$ & $\begin{array}{l}\text { There was a significant increase in the skin conductance } \\
\text { level reflecting the excitation of the sympathetic nervous } \\
\text { system with increase of the speech rate. Further research } \\
\text { is needed to understand the influence of acoustic char- } \\
\text { acteristics of stimuli, task demands, and emotional re- } \\
\text { sponses. }\end{array}$ \\
\hline $\begin{array}{l}\text { McMahon et al., } 2016^{23} \\
\text { Purpose(s): To compare alpha power and pupil dilation } \\
\text { in a sentence perception task in } 15 \text { random levels of } S / N \\
\text { (from }-7 \mathrm{~dB} \text { to }+7 \mathrm{~dB}) \text { under two conditions: highly intel- } \\
\text { ligible ( } 16 \text { channels) and moderately intelligible ( } 6 \text { chan- } \\
\text { nels). }\end{array}$ & Australia & $\begin{array}{l}16 \text { normal hearing } \\
\text { adults and age } \\
\text { between } 19 \text { and } 28 \\
\text { years. }\end{array}$ & $\begin{array}{l}\text { EEG was } \\
\text { performed } \\
\text { in } 16 \text { par- } \\
\text { ticipants and } \\
\text { pupillometry } \\
\text { in } 10 \text { partici- } \\
\text { pants } \\
\end{array}$ & $\begin{array}{l}\text { The results suggest that these objective methods to mea- } \\
\text { sure listening effort and the cognitive processes involved } \\
\text { are still not sufficiently well understood to be used within } \\
\text { a clinical setting. }\end{array}$ \\
\hline $\begin{array}{l}\text { Wagner, Pals, Blecourt, Sarampalis, Başkent, } 2016^{24} \\
\text { Purpose(s): To investigate the time course of lexical } \\
\text { competition and semantic integration when processing } \\
\text { degraded speech. }\end{array}$ & $\begin{array}{l}\text { Nether- } \\
\text { lands }\end{array}$ & $\begin{array}{l}28 \text { Dutch speakers } \\
\text { adults with normal } \\
\text { hearing and age } \\
\text { between } 20 \text { and } 30 \\
\text { years. }\end{array}$ & Pupillometry & $\begin{array}{l}\text { Pupillometry data show that initial semantic integration re- } \\
\text { duces listening effort when phonologically similar words } \\
\text { are separated. }\end{array}$ \\
\hline
\end{tabular}




\begin{tabular}{|c|c|c|c|c|}
\hline Author/year/purpose(s) & Country & Casuistry & $\begin{array}{l}\text { Physiologi- } \\
\text { cal Method }\end{array}$ & Results \\
\hline $\begin{array}{l}\text { Damian, Corona-Strauss, Hannemann, Strauss, } 2015^{25} \\
\text { Purpose(s): To investigate the feasibility of the listening } \\
\text { effort assessment in an environment with a lot of multi- } \\
\text { sensory demand by means of EEG. }\end{array}$ & Germany & $\begin{array}{l}20 \text { normal hearing } \\
\text { adults (mean age } \\
24 \text { years). }\end{array}$ & EEG & $\begin{array}{l}\text { This study shows that mobile devices can be used to } \\
\text { measure listening effort in a situation of multidimensional } \\
\text { conduction. }\end{array}$ \\
\hline $\begin{array}{l}\text { Bertoli, Bodmer, } 2015^{26} \\
\text { Purpose(s): To investigate in two groups of normal lis- } \\
\text { teners whether the magnitude of event-related potentials } \\
\text { increases in an irrelevant novel sound task as far as the } \\
\text { difficulty of the task increases. }\end{array}$ & Switzerland & $\begin{array}{l}18 \text { elderly adults } \\
\text { with normal hear- } \\
\text { ing (mean age } \\
70 \text { years) and } 18 \\
\text { young adults with } \\
\text { normal hearing } \\
\text { (mean age } 23 \\
\text { years). }\end{array}$ & $\begin{array}{l}\text { Event-related } \\
\text { evoked } \\
\text { auditory } \\
\text { potentials. }\end{array}$ & $\begin{array}{l}\text { The amplitudes of Novelty P3 and delayed positive poten- } \\
\text { tial were higher in the young than in the elderly, and with } \\
\text { the increase in task demand, the Novelty P3 had more ro- } \\
\text { bust effects in young and the delayed positive potential in } \\
\text { elderly. Therefore, the use of these potentials to measure } \\
\text { listening effort is relevant, but different analyzes should } \\
\text { be considered. }\end{array}$ \\
\hline $\begin{array}{l}\text { Koelewijna, Kluivera, Shinn-Cunninghamb, Zekveld, } \\
\text { Kramer, } 2015^{27} \\
\text { Purpose(s): To investigate how the response of pupil di- } \\
\text { lation is affected by prior knowledge of location of the } \\
\text { target speech, the beginning of the target speech, and the } \\
\text { speaker. }\end{array}$ & $\begin{array}{l}\text { Nether- } \\
\text { lands }\end{array}$ & $\begin{array}{l}56 \text { young adults } \\
\text { with normal hear- } \\
\text { ing. }\end{array}$ & Pupillometry & $\begin{array}{l}\text { Communicating in a dynamic environment such as a } \\
\text { cocktail party, with excessive environmental noise and } \\
\text { speech, requires a substantial listening effort due to the } \\
\text { demands placed on attentional processes. }\end{array}$ \\
\hline $\begin{array}{l}\text { Zekveld, Heslenfeld, Joshrude, Versfeld, Kramer, } 2014^{28} \\
\text { Purpose(s): to identify the neural related of the pupil dila- } \\
\text { tion during the sentences understanding with degraded } \\
\text { speech signal in } 17 \text { normal hearing individuals. }\end{array}$ & $\begin{array}{l}\text { Nether- } \\
\text { lands }\end{array}$ & $\begin{array}{l}17 \text { normal hearing } \\
\text { adults and age } \\
\text { between } 19 \text { and } 33 \\
\text { years. }\end{array}$ & Pupillometry & $\begin{array}{l}\text { The pupil dilatation during the speech perception in chal- } \\
\text { lenging situations reflects the auditory and cognitive pro- } \\
\text { cesses. }\end{array}$ \\
\hline $\begin{array}{l}\text { Bernarding, Strauss, Hannemann, Corona-Strauss, } \\
2012^{29} \\
\text { Purpose(s): To propose a new measure to quantify the } \\
\text { listening effort on a large scale using the EEG. }\end{array}$ & $\begin{array}{c}\text { The United } \\
\text { States of } \\
\text { America }\end{array}$ & $\begin{array}{l}13 \text { normal hearing } \\
\text { adults (mean age } \\
\text { of } 24 \text { years). }\end{array}$ & EEG & $\begin{array}{l}\text { The results demonstrate that additional research should } \\
\text { include the development of listening tasks that require } \\
\text { greater effort to reveal differences between the auditory } \\
\text { paradigms. }\end{array}$ \\
\hline $\begin{array}{l}\text { Mackersie, Cone, } 2011^{7} \\
\text { Purpose(s): a) to determine if the physiological indexes } \\
\text { of listening effort are more sensitive than the subjective } \\
\text { measures during a speech task; b) to determine the rela- } \\
\text { tive sensitivity of four physiological measures to changes } \\
\text { in task demand, and c) to determine the relations between } \\
\text { changes in physiological measures and changes in sub- } \\
\text { jective stress and cognitive load ratings. }\end{array}$ & $\begin{array}{c}\text { The United } \\
\text { States of } \\
\text { America }\end{array}$ & $\begin{array}{l}15 \text { normal hearing } \\
\text { adults (mean age } \\
27 \text { years). }\end{array}$ & $\begin{array}{l}\text { Heart rate, } \\
\text { skin conduc- } \\
\text { tance, skin } \\
\text { temperature } \\
\text { and EMG } \\
\text { activity. }\end{array}$ & $\begin{array}{l}\text { There was a significant increase in skin conductance } \\
\text { and EMG activity as the demand of the listening task in- } \\
\text { creased. The heart rate and skin temperature did not alter } \\
\text { significantly. There was no strong association between } \\
\text { subjective and physiological measures. }\end{array}$ \\
\hline $\begin{array}{l}\text { Bernarding et al., } 2011^{30} \\
\text { Purpose(s): To explore the effects on the synchronization } \\
\text { stability in the wavelet phase using two simulations of } \\
\text { hearing loss and HA. }\end{array}$ & $\begin{array}{c}\text { The United } \\
\text { States of } \\
\text { America }\end{array}$ & $\begin{array}{l}14 \text { normal hearing } \\
\text { adults (mean age } \\
26 \text { years). }\end{array}$ & $\begin{array}{l}\text { Long-La- } \\
\text { tency Audi- } \\
\text { tory Evoked } \\
\text { Potential. }\end{array}$ & $\begin{array}{l}\text { The results showed that, in the case of a simultaneous } \\
\text { simulation of hearing loss with the use of noise masking } \\
\text { and a HA, objective discrimination between an easy and a } \\
\text { difficult listening situation can be achieved. }\end{array}$ \\
\hline $\begin{array}{l}\text { Zekveld, Kramer; Festen, } 2010^{31} \\
\text { Purpose(s): To evaluate the influence of } \\
\text { the sentences intelligibility in the pupil dilation response } \\
\text { during different listening situations. }\end{array}$ & $\begin{array}{c}\text { The United } \\
\text { States of } \\
\text { America }\end{array}$ & $\begin{array}{l}38 \text { normal hearing } \\
\text { adults (mean age } \\
23 \text { years). }\end{array}$ & Pupillometry & $\begin{array}{l}\text { The results support that the listening effort, as indicated } \\
\text { by the pupil response, increases with the decrease of } \\
\text { speech intelligibility. This study indicates that pupillometry } \\
\text { can be used to examine how listeners achieve a certain } \\
\text { level of performance. }\end{array}$ \\
\hline $\begin{array}{l}\text { Bernarding, Corona-Strauss, Latzel, Strauss, } 2010^{32} \\
\text { Purpose(s): To estimate listening effort with the use of } \\
\text { WPSS synchronization of long-latency evoked potentials } \\
\text { using two different paradigms with different signal-to- } \\
\text { noise ratios to mimic environments with different noise } \\
\text { levels. }\end{array}$ & $\begin{array}{c}\text { The United } \\
\text { States of } \\
\text { America }\end{array}$ & $\begin{array}{l}21 \text { normal hearing } \\
\text { adults (mean age } \\
25 \text { years). }\end{array}$ & $\begin{array}{l}\text { Long-La- } \\
\text { tency Audi- } \\
\text { tory Evoked } \\
\text { Potential. }\end{array}$ & $\begin{array}{l}\text { WPSS is a robust measure to realize the differences be- } \\
\text { tween the effort required to perform tasks in easy and } \\
\text { difficult listening conditions, but additional research with } \\
\text { the hearing-impaired individuals will be relevant to prove } \\
\text { the applicability of this method to improve HA fitting pro- } \\
\text { cedures. }\end{array}$ \\
\hline
\end{tabular}

Legend: $\mathrm{HA}=$ Hearing aids, EEG = Electroencephalography, ECG = Electrocardiogram, EMG = Electromyography, P3 = Long-Latency Auditory Evoked Potential P300, $(\mathrm{S} / \mathrm{N})=$ Signal-to-noise ratio, WPSS = Wavelet phase synchronization stability..

Figure 3. Synthesis of selected studies for the analysis of physiological methods of listening effort assessment in normal hearing individuals $(n=18)$ 
Some authors state the relevance of conducting new research to determine the physiological aspects ${ }^{21,32}$ and the cognitive demands involved in speech processing in different signal-to-noise ratios, with acoustic stimuli that present distinct characteristics and, considering the emotional responses of the individuals assessed ${ }^{21,22}$.

It is worth mentioning that two studies measured the listening effort both subjectively and objectively, and found that the difference of the methods used in the assessment represented differences in the cognitive processes involved ${ }^{16,20}$.

Some studies measured the listening effort of normal hearing individuals with the use of long-latency auditory potentials ${ }^{26,30,32}$ and the authors noticed that these measures were able to detect differences in the auditory cortical pathways when individuals performed the necessary listening effort to perform speech perception tasks, and even understand speech under distinct listening conditions such as in silence and in noise. A study that used the Event-Related Auditory Evoked Potential ${ }^{26}$ as a listening effort index aimed to compare the performance of young and old adults. The analysis of the findings showed that the amplitudes of Novelty P3 and the delayed positive potential were higher in young people than in the elderly, and that with the increase of the task demand, the Novelty P3 presented more robust effects in the young people and the delayed positive potential in the elderly people.

The present literature review demonstrates that the physiological methods used to the listening effort measurement seem to be sensitive to different experimental conditions, and for this reason, new research that adopt other study designs in this measurement is required.

In addition, it is evident that studies in this area are relatively recent, since of the 18 selected articles, $72 . \%^{16-28}$ are from the last five years. It should also be noted that the analysis of the articles revealed the lack of national studies that measured the listening effort using physiological indexes as a method of measuring this parameter in both normal hearing individuals and hearing-impaired individuals. It is also worth noting that in the international literature $50 \%$ of the studies were conducted in the United States ${ }^{7,17,20-22,29-32}$, $22,2 \%$ in Netherlands $18,24,27,28,11,1 \%$ in Australia $^{6,23}$ and $5.5 \%$ respectively in Denmark ${ }^{19}$, Germany ${ }^{25}$, and Switzerland ${ }^{26}$.

In front of the relevance of studying and researching the cognitive processes involved in speech perception and its effort to understand it, it would be essential to continue the investigations that contribute to the discovery of the most accurate physiological index for the listening effort measurement, in order to benefit individuals with hearing loss in their speech comprehension process in daily situations.

\section{CONCLUSION}

This study presented a literature review about the physiological indexes most commonly used for the listening effort measurement of normal-hearing individuals, and it was concluded that there is no consensus among researchers with respect to the best physiological method to measure this auditory parameter, that is, this effort in the speech perception tasks, although the skin conductance level was considered the most accurate measure for this measurement.

\section{REFERENCES}

1. Gatehouse S, Noble W. The speech, spatial and qualities of hearing scale (SSQ). Int J Audiol. 2004;43(2):85-99.

2. Gatehouse $S$, Akeroyd M. Two-eared listening in dynamic situations. Int J Audiol. 2006;45(Suppl 1):S120-4.

3. Humes LE. Dimensions of hearing aid outcome. J Am Acad Audiol. 1999;10(1):26-39.

4. Goldwater BC. Psychological significance of pupillary movements. Psychol Bull. 1972;77(5):340-55.

5. Kramer SE, Kapteyn TS, Festen JM, Kuik DJ. Assessing aspects of auditory handicap by means of pupil dilatation. Audiology. 1997;36(3):155-64.

6. Zekveld AA, Kramer SE, Festen JM. Pupil response as an indication of effortful listening: the influence of sentence intelligibility. Ear Hear. 2010;31(4):480-90.

7. Mackersie $\mathrm{CL}$, Cones $\mathrm{H}$. Subjective and psychophysiological indexes of listening effort in a competing-talker task. J Am Acad Audiol. 2011;22(2):113-22.

8. Fournier LR, Wilson GF, Swain CR. Electrophysiological, behavioral, and subjective indexes of workload when performing multiple tasks: manipulations of task difficulty and training. Int J Psychophysiol. 1999;31(2):129-45.

9. Wilson GF, Russell CA. Real-time assessment of mental workload using psychophysiological measures and artificial neural networks. Hum Factors. 2003;45(4):635-44. 
10. Richter M, Friedrich A, Gendolla GHE. Task difficulty effects on cardiac activity. Psychophysiology. 2008;45(5):869-75.

11. Backs RW, Seljos KA. Metabolic and cardiorespiratory measures of mental effort: The effects of level of difficulty in a working memory task. Int J Psychophysiol. 1994;16(1):57-68

12. Veltman JA, Gaillard AWK. Physiological workload reactions to increasing levels of task difficulty. Ergonomics. 1998;41(5):656-69.

13. McGarrigle R, Munro KJ, Dawes $P$, Stewart AJ, Moore DR, Barry JG et al. Listening effort and fatigue: what exactly are we measuring? A British Society of Audiology Cognition in Hearing Special Interest Group 'white paper'. Int J Audiol. 2014;53(7):433-40.

14. Mendes KDD, Silveira RCCP, Galvão CM. Revisão integrativa: método de pesquisa para a incorporação de evidências na saúde e na enfermagem. Texto \& Contexto Enferm. 2008;17(4):758-64.

15. Whittemore R, Knafl K. The integrative review: updated methodology. J Adv Nurs. 2005;52(5):546-53.

16. Miles K, Mc Mahon C, Boisvert I, Ibrahim R, de Lissa P, Graham $P$ et al. Objective assessment of listening effort: coregistration of pupillometry and EEG. Trends Hear. 2017;21:1-13.

17. McGarrigle R, Dawes P, Stewart AJ, Kuchinsky SE, Munro KJ. Measuring listening-related effort and fatigue in school aged children using pupillometry. J Exp Child Psychol. 2017;161:95-112.

18. Wagner AE, Toffanin P, Baskent D. The timing and effort of lexical access in natural and degraded speech. Front. Psychol. 2016;7(398):1-14.

19. Bianchi F, Santurette S, Wendt D, Dau T. Pitch discrimination in musicians and non-musicians: effects of harmonic resolvability and processing effort. J. Assoc. Res. Otolaryngol. 2016;17(1):69-79.

20. Wendt D, Dau T, Hjortkjær J. Impact of background noise and sentence complexity on processing demands during sentence comprehension front. Psychol. 2016;7(345):1-12.

21. Francis AL, MacPherson MK, Chandrasekaran $B$, Alvar AM. Autonomic nervous system responses during perception of masked speech may reflect constructs other than subjective listening effort. Front. Psychol. 2016;7(263):1-15.

22. Mackersie CL, Calderon-Moultrie N. Autonomic nervous system reactivity during speech repetition tasks: heart rate variability and skin conductance. Ear Hear. 2016;37(1):118S-25S.

23. McMahon, Boisvert I, de Lissa P, Granger L, Ibrahim R, Lo CY et al. Monitoring alpha oscillations and pupil dilation across a performance-intensity function. Front. Psychol. 2016;7(745):1-12.

24. Wagner A, Pals C, Blecourt CM, Sarampalis A, Başkent $D$. Does signal degradation affect top-down processing of speech? In: Van Dijk $P$, Başkent D, Gaudrain E, Kleine E, Wagner A, Lanting C (orgs). Physiology, psychoacoustics and cognition in normal and impaired hearing. Switzerland: Springer Open, 2016. p. 297-306.

25. Damian A, Corona-Strauss FI, Hannemann $R$, Strauss DJ. Towards the assessment of listening effort in real life situations: mobile EEG recordings in a multimodal driving situation. IEEE. 2015;2015(1):8123-6.

26. Bertoli S, Bodmer D. Effects of age and task difficulty on ERP responses to novel sounds present during a speech perception in noise test. Clin Neurophysiol. 2016;127(1):360-8.

27. Koelewijna $T$, Kluivera $H$, Shinn-Cunninghamb BG, Zekvelda AA, Krame SE. The pupil response reveals increased listening effort when it is difficult to focus attention. Hear Res. 2015;323:81-90.

28. Zekveld AA, Heslenfeld DJ, Joshrude IS, Versfeld NJ, Kramer SE. The eye as a window to the listening brain neural correlates of pupil size as a measure of cognitive listening load. Neuroimage. 2014;101:76-86.

29. Bernarding C, Strauss DJ, Hannemann R, CoronaStrauss FI. Quantification of listening effort correlates in the oscillatory EEQ activity: a feasibility study. IEEE. 2012;2012(1):4615-8.

30. Bernarding C, Strauss DJ, Latzel M, Hannemann R, Chalupper J, Corona-Strauss FI. Simulations of hearing loss and hearing aid: effects on electrophysiological correlates of listening effort. IEEE. 2011;2011(1):2319-22.

31. Zekveld AA, Kramer SE, Festen JM. Pupil response as an indication of effortful listening: the influence of sentence intelligibility. Ear Hear. 2010;31 (4):480-90.

32. Bernarding C, Corona-Strauss FI, Latzel M, Strauss DJ. Auditory streaming and listening effort: an event related potential study. IEEE. 2010;2010(1):6817-20. 